Top experts on the challenge of

hyper- and hypocortisolism management

\title{
Cortisol Excess \\ and Insufficiency
}

Editors: Emanuela Arvat

Alberto Falorni

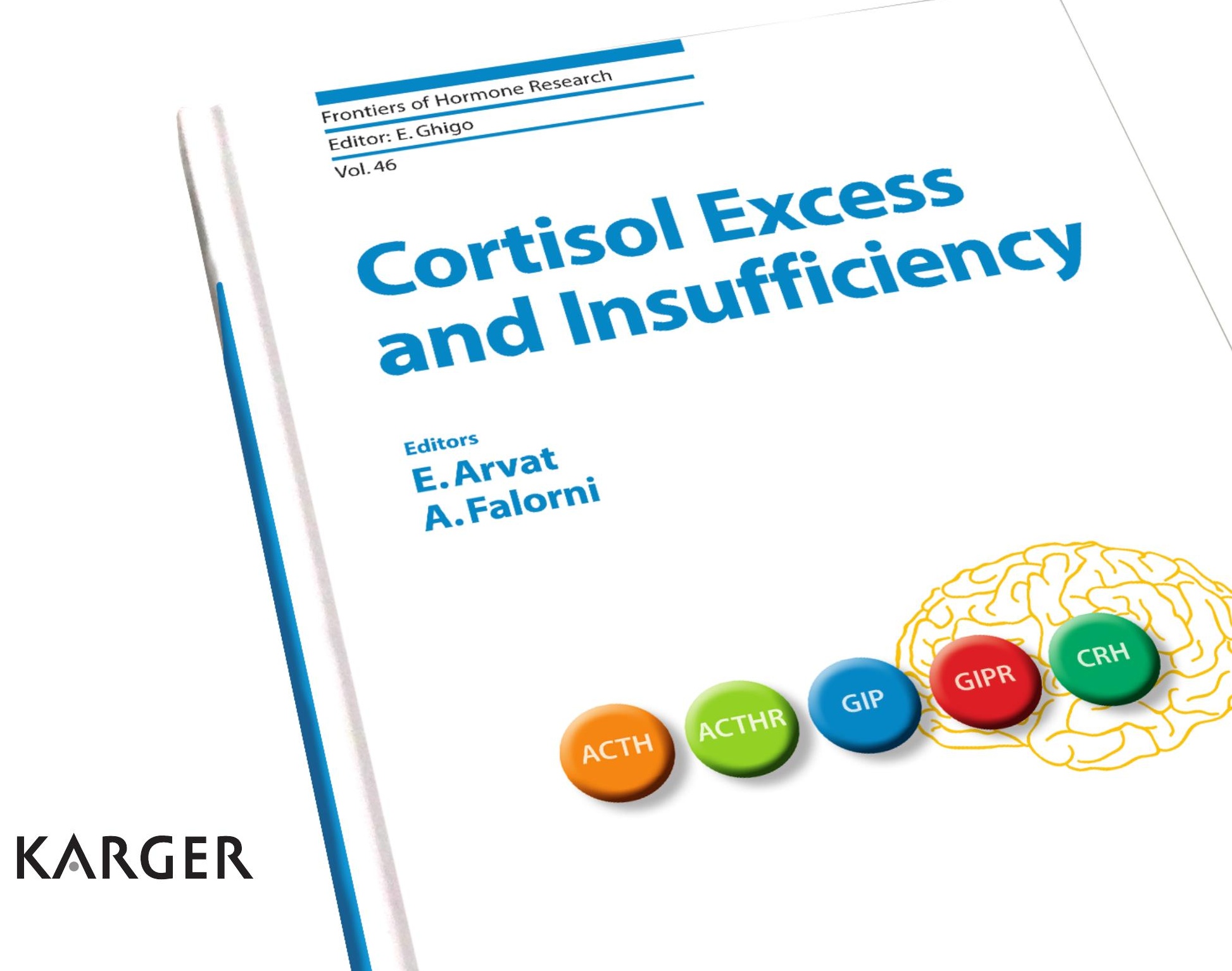




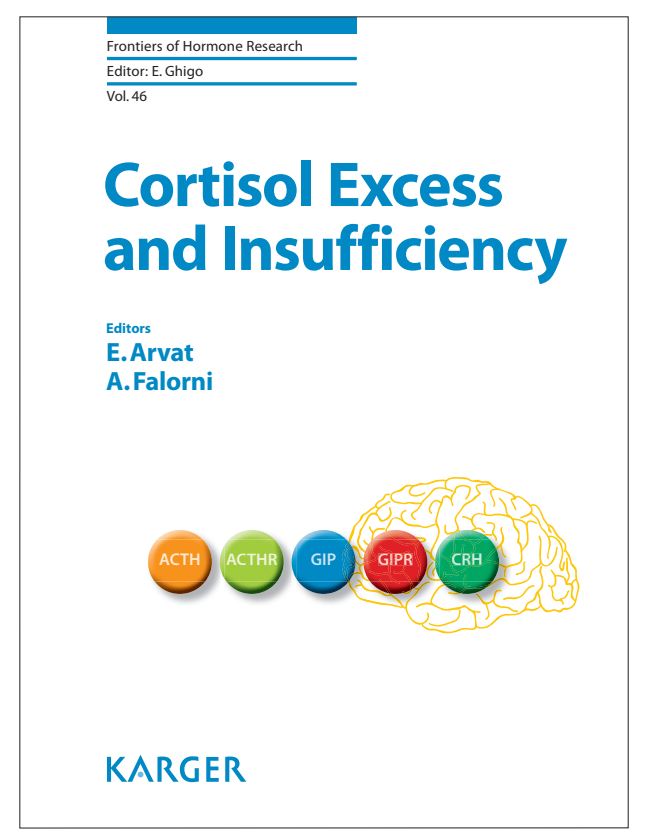

Disorders associated with cortisol excess and insufficiency, although rare, deserve the attention of the entire medical community because of high associated morbidity and mortality. Both diagnosis and management of hypo- and hypercortisolism are challenging, and disease presentation at both clinical and laboratory level is not always definite. New tools are available for non-invasive and early diagnosis, and the choice of treatment should be tailored to each patient to improve quality of life through the regulation of the levels and rhythm of hormonal secretion, while limiting complications associated with the disease and therapies. In this new volume, top experts have contributed chapters on the pathognomonic, epidemiological, clinical, radiological, and laboratory aspects of the various disorders associated with altered cortisol secretion. They also present information on still debated standpoints on management. Cortisol Excess and Insufficiency is a valuable reference book for those wishing to have a reasoned and broad overview of the pathophysiology and management of disorders associated with hypo-and hypercortisolism.
Frontiers of Hormone Research, Vol. 46

\section{Cortisol Excess and Insufficiency}

Editors: Arvat, E. (Turin); Falorni A. (Perugia)

VIII + 216 p., 17 fig., 4 in color, 20 tab., 2016

CHF 196.00 / EUR 183.00 / USD 231.00 (hard cover or online*)

CHF 235.00 / EUR 220.00 / USD 277.00 (online $^{* *}$ )

ISBN 978-3-318-05839-0

e-ISBN 978-3-318-05840-6

FIELDS OF INTEREST: Endocrinology; Internal Medicine; Neuroendocrinology, Immunology, Laboratory, Metabolism

\section{CONTENTS}

Preface: Arvat, E.; Falorni, A.; Ghigo, E.; Guaraldi, F.

Pseudo-Cushing - A Clinical Challenge?: Pecori Giraldi, F.; Ambrogio, A.G.

Cushing's Syndrome: Where and How to Find It: Debono, M.; Newell-Price, J.D.

Subclinical Hypercortisolism: How to Deal with It?: Chiodini, I.; Morelli, V.

Etiopathogeny of Primary Adrenal Hypercortisolism: Vélayoudom-Céphise, F.-L.; Haissaguerre, M.; Tabarin, A.

Metabolic Alterations and Cardiovascular Outcomes of Cortisol Excess: Pivonello, R.; De Martino, M.C.; Iacuaniello, D.; Simeoli, C.; Muscogiuri, G.; Carlomagno, F.; De Leo, M.; Cozzolino, A.; Colao, A.

Skeletal Fragility in Endogenous Hypercortisolism: Mazziotti, G.; Delgado, A.; Maffezzoni, F.; Formenti, A.; Giustina, A.

Cortisol Excess and the Brain: Resmini, E.; Santos, A.; Webb, S.M.

Update on Hypercortisolism Therapy: Arnaldi, G.; Trementino, L.

Is Adrenal Insufficiency a Rare Disease?: Dahlqvist, P.; Isaksson, M.; Bensing, S.

From Genetic Predisposition to Molecular Mechanisms of Autoimmune Primary Adrenal Insufficiency: Falorni, A.; Brozzetti, A.; Perniola, R.

From Appearance of Adrenal Autoantibodies to Clinical Symptoms of Addison's Disease: Natural History: Betterle, C.; Garelli, S.; Presotto, F.; Furmaniak, J.

Is Diagnosis and Subclassification of Adrenal Insufficiency as Easy as It Looks?: Smans, L.C.C.J.; Zelissen, P.M.J.

Secondary Adrenal Insufficiency: Where Is It Hidden and What Does It Look Like?: Guaraldi, F.; Karamouzis, I.; Berardelli, R.; D’Angelo, V.; Rampino, A.; Zichi, C.;

Ghigo, E.; Giordano, R.

Quality of Life and Life Expectancy in Patients with Adrenal Insufficiency: What Is True and What Is Urban Myth?: Burger-Stritt, S.; Pulzer, A.; Hahner, S.

Congenital Adrenal Hyperplasia: Unresolved Issues: Yau, M.; Khattab, A.; Poppas, D.; Ghizzoni, L.; New, M.

Adrenal Insufficiency Therapy: How to Keep the Balance between Good Quality of Life and Low Risk for Long-Term Side Effects?: Simunkova, K.; Husebye, E.S.

Author Index/Subject Index
Orders can be placed at agencies, bookstores, directly with the publisher, or with any Karger distributor.

S. Karger AG, P.O. Box, 4009 Basel (Switzerland) e: orders@karger.com, f: +41613061234

USA: S. Karger Publishers, Inc., 26 West Avon Road, P.O. Box 529, Unionville, CT 06085, Toll free: +1-800-828-5479

Germany: S. Karger GmbH, 79095 Freiburg

France: Enter \& Read, Albertine Luginbuhl, 75014 Paris

Japan: Karger Japan, Inc., Tokyo 105-0012

South East Asia, China and Taiwan: Karger Regional Office (Malaysia)

46050 Petaling Jaya, Selangor Darul Ehsan

Argentina, Brazil, Chile, Mexico, Uruguay: dot.lib, 01418-000 São Paulo

India, Bangladesh, Sri Lanka: Karger India, New Delhi 110016

Thailand: S. Karger, Nakhon Pathom 73170

Russian Federation: World of Periodicals, Moscow 125190

South Eastern Europe (w/o Greece)-for books only: Dr. László Horváth, 1047 Budapest

For details and further representatives and agencies see:

www.karger.com/worldwide
Library Recommendation

\section{Dear Librarian}

I have reviewed Cortisol Excess and Insufficiency and would like to recommend it for your library

Recommended by:

Department:

Date:

Signature:

ebooks are available on

amazon > Google play Vitalsource 

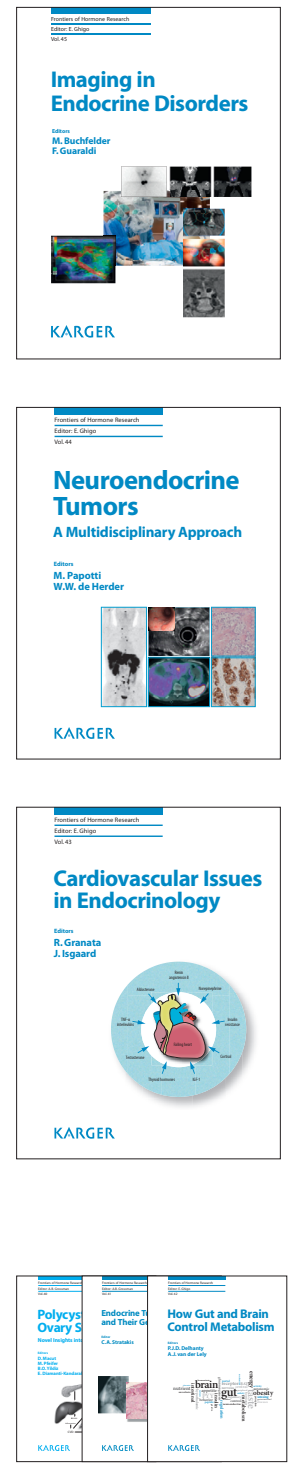

Imaging in Endocrine Disorders

Editors: Buchfelder, M. (Erlangen);

Guaraldi, F. (Turin)

VIII + 156 p., 141 fig., 33 in color, 9 tab., 2016

CHF 180.00 / EUR 168.00 / USD 212.00

(hard cover or online*)

CHF 216.00 / EUR 202.00 / USD 254.00 (online**)

ISBN 978-3-318-02737-2

e-ISBN 978-3-318-02738-9

Vol. 44

\section{Neuroendocrine Tumors:}

\section{A Multidisciplinary Approach}

Editors: Papotti, M. (Turin);

de Herder, W.W. (Rotterdam)

$X+270$ p., 51 fig., 26 in color, 27 tab., 2015

CHF 216.00 / EUR 202.00 / USD 254.00

(hard cover or online*)

CHF 259.00 / EUR 242.00 / USD 305.00 (online**)

ISBN 978-3-318-02772-3

e-ISBN 978-3-318-02773-0

Vol. 43

Cardiovascular Issues in Endocrinology

Editors: Granata, R. (Turin);

Isgaard, J. (Gothenburg)

$X+164$ p., 18 fig., 2 in color, 10 tab., 2014

CHF 163.00 / EUR 152.00 / USD 192.00

(hard cover or online*)

CHF 196.00 / EUR 182.00 / USD 230.00 (online**)

ISBN 978-3-318-02673-3

e-ISBN 978-3-318-02674-0

\section{Book Series}

\section{Frontiers of Hormone Research}

Series Editor: Ghigo, E.; Guaraldi, F. (Turin)

ISSN 0301-3073

eISSN 1662-3762

Listed in MEDLINE/PubMed,

Thomson Reuters indices

Vol. 1-45 available, please ask for details

\section{www.karger.com/fhore}

*online prices for personal customer

**online prices for institutional purchase

Prices subject to change, VAT not included.

EUR price for eurozone countries,

USD price for USA and Latin America only

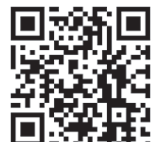

www.karger.com/fhore

\section{D.E. Matthews • V.T. Farewell}

Using and

Understanding

Medical

Statistics

\section{5th, revised and extended edition}

D.E. Matthews - V.T. Farewell

\section{Using and Understanding Medical Statistics}

5th, revised and extended edition

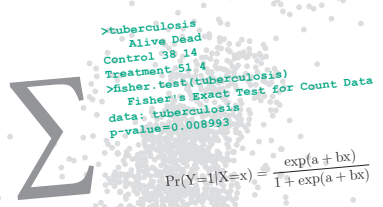

KARGER

XX + 338 p., 48 fig., 103 tab., 2015

CHF 49.00 / EUR 46.00 / USD 54.00

(hard cover + online supplementary material)

ISBN 978-3-318-05458-3

e-ISBN 978-3-318-05459-0 